Sophie Roborgh - Beyond Medical Humanitarianism

\title{
Beyond Medical Humanitarianism - Politics and Humanitarianism in the Figure of the Mīdānī Physician
}

\begin{abstract}
This article explores the complex position of local physicians at times of political unrest or conflict, conceptualizing local medical voluntarism as a form of collective action. It analyzes the evolving interpretation of medical neutrality among Egyptian physicians who provided medical assistance to injured protesters in the Egyptian uprising (2011-2013). In-depth interviews with 24 medical and nonmedical volunteers on their perception of medical neutrality were matched with their mobilization and participation history, showing the extent towards which political considerations influenced their voluntary medical engagement. The results firstly show that revolutionary political considerations played a central role in the physicians' mobilization into medical networks active in the protests, as well as in their interpretation of their medical and non-medical activities. Secondly, I argue that the interpretation of medical neutrality among Egyptian physicians evolved significantly over time. A special type of medical volunteer took shape, the mìdānī physician. This physician openly expresses his/her political convictions and adheres to (self-defined) humanitarian principles through a conscious reconciliation of the two. The article details the increasing difficulty of this task after the revolutionary movement splintered into competing factions and citizens ended up fighting each other instead of authoritarian rule.
\end{abstract}

Keywords: medical neutrality; medical sociology; medical personnel; Egypt; social movements; mobilization; humanitarianism

Research highlights:

1) Traces local medical mobilization in the Egyptian uprising (2011-2013).

2) Explores reconciliation of political and humanitarian goals. 
Sophie Roborgh - Beyond Medical Humanitarianism

3) Introduces the 'mīdān' health worker concept.

\section{Introduction}

Physicians played an important role in the wave of protests which swept countries of the Middle East and North Africa from December 2010 onwards. In Syria, Bahrain, Egypt, Yemen, and Libya, healthcare to injured protesters was offered by (inter)national humanitarian organizations and local civilian doctors. This article focuses on local physicians, and to a more limited degree other health workers, who face a specific set of circumstances and professional and ethical challenges as health workers in a society where conflict or political unrest erupts. This is also the case in Egypt, where in the period of January 2011 until August 2013 local physicians were a fixture within Cairo's protests and sit-ins.

Through organizations such as the 'Tahrir Doctors Society' (TDS), physicians offered healthcare assistance through a network of field hospitals and medical clinics. Physicians in this medical network $(\mathrm{MN})$ partook in both medical and non-medical activities, including provision of emergency care and first aid, running of out-patient facilities, organization of medical caravans, establishment of shelters and distribution centers of medical and non-medical products, training of paramedics and the next generation of medics, forensic medicine, and advising on prevention of injuries. Additionally, they were involved in practices of witnessing (témoignage) in national and international media, and took on leadership and mediation roles within the broader revolutionary community.

The experience of local physicians is even more complex than the position of international humanitarian staff in times of conflict. Local physicians in the Egyptian context are simultaneously citizens, protesters, and members of a profession. While they may suffer financial hardship 
Sophie Roborgh - Beyond Medical Humanitarianism

individually, they occupy a privileged position in other, sociocultural, ways. Physicianhood continues to be a source of pride for Egyptian families. They are regarded as part of the social elite and hence share 'a sense of social responsibility' towards the population (Rosefsky Wickham 1997: 122-123; 129). These circumstances affect the manner in which they attribute meaning to their actions, constitute a collective identity, and shape the interaction between the clinic and protest environment. Instead of (predominantly non-local) salaried humanitarian professionals, operating in a society to which they often do not have a long-term connection (Slim 2015:13; Barnett and Weiss 2008:31), they are locals who happen to find themselves in a situation where they possess a strategically relevant skill. This difference in position requires a shifting of the paradigm and interpretive framework through which their engagement in the protests should be understood. Moreover, as the characteristics of protest events evolved, the activities of MN physicians and their own interpretation of them changed as well.

There are a limited number of contributions on local health workers' activities during times of conflict (see Adams 1998; Iliffe 1998; Dewachi 2017; Abramowitz and Panter-Brick 2015). The Arab uprisings have galvanized efforts in the field, for instance on Turkey (Aciksoz 2016) and Egypt (Hamdy and Bayoumi 2016). The plight of Syrian health workers in particular has resulted in renewed interest in the local medical response. Oftentimes these contributions focus on the attacks the medical sector faces (Rubenstein 2013; Fouad, Sparrow, et al. 2017). This article contributes to the few works currently available on local health workers' considerations, and experiences in times of conflict and political unrest (see also Footer, et al. 2014:385; Peterson 2015:6; Sousa and Hagopian 2011; Aciksoz 2016).

It analyzes the role political convictions played in their motivation to mobilize in the first place, and in their continued participation (and eventual demobilization) in MN. Exploring the political element within humanitarianism is not without controversy. In analyzing the politicization of local medical 
Sophie Roborgh - Beyond Medical Humanitarianism

assistance, this contribution does not seek to detract from the beneficial activities that these local physicians engaged in, often at significant personal cost. Instead, it aims to further inform the debate on the engagement of local physicians with humanitarianism. It also elaborates how their interpretation of their activities evolves and can take on new (political) meaning. These issues are especially pertinent in a time of increasing localization of humanitarian assistance, including medical assistance (Schenkenberg van Mierop 2016b).

\section{The Egyptian context}

Egypt experienced a time of profound political unrest in the period under study (January 2011-August 2013), resulting in sustained protest activities undertaken by different coalitions of protesters against rapidly changing rulers. Crucially, these fast changes provide the study with a de facto longitudinal element. Despite the relatively brief period under study (2.5 years), these changes offer a rare opportunity to analyze how the MN adapted to different levels of restriction under subsequent rulers, and engaged with various protest bodies, while controlling for medico-cultural and socio-economic context.

The following limited timeline is based on a larger one, drawing on several hundred open source media and policy publications on the protest events, in addition to academic publications. After years of labor protests, driven by decreased living standards and increased political oppression, and emboldened by the successful Tunisian revolution, Egyptians took to the streets against President Hosni Mubarak in January 2011. The protesters were able to oust Mubarak in February 2011 after which the Supreme Council of the Armed Forces (SCAF) took control for 17 months. SCAF was also subjected to mass protests, as different political factions sought to fill the power vacuum, and fought to secure revolutionary gains (Abdelrahman 2015). Protests occurred during 'Mohamed Mahmoud' (November 2011), where protesters protested among others the SCAF's increasingly assertive rule and pushed for a handover to civilian rule. An estimated 45-47 protesters died and over 2000 were 
Sophie Roborgh - Beyond Medical Humanitarianism

injured in the violent state response that followed (Ahram Online 2011a, 2011b, 2012b; Feteha and Tarek 2011; HRW 2012b). In the 'Cabinet clashes' (December 2011), protester demands remained unchanged, as they challenged the selection of new prime minister Kamāl al-Ganzūrī. Violence escalated when the army took a more pro-active role in combating the protests, resulting in 17-19 deaths and 750-928 wounded (Ahram Online and Feteha 2011; Ahram Online 2011b; El Gundy 2011; Abouzeid 2011; Eskandar 2012; Al-Khalfwai 2013). Another large protest moment followed in 'Abāsīya (May 2012), when popular Islamist presidential candidate Ḥāzim Șalāḥ ’Abū ’Ismā'îl was excluded from the presidential race. After several days, death rate estimates ranged between 11 and 20, and over 373 were injured (CNN Wire Staff 2011, 2012; Shams El-Din 2011; Egypt Independent 2012; Ahram Online 2012a; US Embassy in Egypt 2012; RT 2012; AlArabiya with agencies 2012; HRW 2012a). Muslim Brotherhood member Mohamed Morsy took his seat as new President in June 2012. However, he similarly reached for authoritarian measures to navigate Egypt's complex postrevolutionary political system, drawing rebuke from his political opponents and triggering mass protests (Ali 2012; HRW 2012c). In 'al-Ittihādīya' (December 2012), a sit-in in front of the Presidential al-Ittihādīya palace turned sour. Muslim Brotherhood sympathizers attacked the antiBrotherhood protesters, and Egyptian civilians targeted each other in street battles. Death estimates ranged from two to nine and hundreds were injured. (CIHRS 2012:8, 13, 24; Shukrallah, et al. 2012; Ahram Online and Hussein Rashwan 2012; El-Sharnoubi, et al. 2012). Morsy's rule remained mired with weekly protests, quickly gaining momentum when in April 2013 Tamarrud was formed. This anti-Morsy grassroots movement called for large scale protests on the one year anniversary of Morsy's rule on 30 June 2013 (Alexander and Bassiouny 2014:311; BBC 2013). In response, support rallies and sit-ins were organized by Morsy's supporters in Rābi 'a al- 'Adawiyya square and in alNahḍa square. In July 2013, SCAF, led by Minister of Defense and Commander-in-Chief (and later President) al-Sisi, announced Morsy had been ousted. They could count on the support of leftists, centrist forces, ancien régime, Salafists, and Coptic clergy in this "popular coup". In the four days of protests that followed, 57 were killed. Muslim Brothers vehemently protested the coup (AFP 2013), 
Sophie Roborgh - Beyond Medical Humanitarianism

and a decisive crackdown followed on 14 August 2013. In the euphemistically titled one day “evacuation” of the sit-ins in Rābi a al- 'Adawiyya and al-Nahḍa squares, more than 817 — and likely over 1000 — protesters died and thousands were injured in Rābi 'a alone, with 87 deaths occurring in al-Nahḍa (HRW 2014: 6, 11, 102). These events are merely a selection of the many protests and violent crackdowns that occurred. They have been elaborated here, as they played a key role within the mobilization and participation process of the MN physicians, and specifically feature in this study.

\section{The medical network}

As its name implies, the MN consists of a wide range of actors, groups, and initiatives both formal and informal. Partially due to the MN's multi-faceted nature and the ad-hoc participation of many of its contributors, the total number of medical and non-medical volunteers in $\mathrm{MN}$ is unclear. However, the nascent Tahrir Doctors Society (TDS) reported that in the '18 days' revolution against Mubarak (January-February 2011), it had a list with over 600 health workers who wanted to contribute to the medical response. The Egyptian Medical Syndicate, meanwhile, lauded over 300 people who had greatly contributed to the medical efforts during these protests in Egypt. This means that hundreds, and potentially even more than a thousand physicians and other health workers (in the making) may have been involved in providing medical support in Cairo alone.

Most notable among the groups is TDS, which was officially established in March 2011. The organization peaked during Muhamad Mạ̣mūd with an estimated 200-250 active volunteers, but saw its numbers decrease thereafter. At the time of the interviews with members of the organization (August-September 2014), they estimated that there were approximately 25-50 active members left. Due to their longevity they feature extensively in the analysis. The informal Kentucky Revolutionary Clinic (KRC) was known for its location in front of Taḥrīr Square's Kentucky Fried Chicken branch. KRC had approximately 32 active members, including medical and non-medical volunteers. It evolved into an important primary response point and one of the most media-savvy MN organizations. 
Sophie Roborgh - Beyond Medical Humanitarianism

It unfortunately suffered from organizational infighting, hampering its continuing effectiveness. The Muslim Brotherhood similarly engaged in emergency response. However, they initially mostly drew on the Brotherhood-dominated Arab Medical Union (AMU). The Brotherhood largely relied on its own medical response structure in the Rābi a and Nahḍa sit-ins. The medical team of the Qașr alDūbāra Evangelical Church was another key contributor. Their field hospital was especially important in the Muḥamad Maḥmūd and Cabinet clashes. During Muhamad Maḥmūd, 500 injured protesters were helped here on a daily basis, assisted by approximately 180 volunteers connected to the church (Shub‘ān 2012). The church continued its medical support afterwards (Al-Bedaiah 2013). Several student groups were part of $\mathrm{MN}$, among which the 'Alà' 'Abd al-Hādī group, named after the beloved young medical student who was killed in the Cabinet clashes, is the most well-known. However, most of the medical volunteers engaged in MN remained independent. Moving between different field hospitals, they helped in information sharing, spread of best practices, and supplies provision. Often they engaged in medical assistance on an ad-hoc basis, bringing along basic medical supplies when joining the protests. Finally, non-medical volunteers played an important role, as communities became involved in the medical effort. Every protester and neighborhood resident was a potential paramedic. Some non-medical volunteers even ended up occupying leading roles in MN organizations.

\section{Humanitarianism, medical neutrality, and politics}

Disease and healthcare provision, as well as humanitarianism more broadly, have a long history of politicization, and physicians have often engaged in activities that exceeded their clinical and therapeutic functions.

Humanitarianism remains a concept that is less defined, with Slim attributing this 'boundary problem' to the wide-ranging and contested interpretation of the actors, methodology and context (2015:8). Interpretations move on a spectrum between a narrower one, emphasizing limited, life-saving 
Sophie Roborgh - Beyond Medical Humanitarianism

assistance in acute emergencies (ibid.:10), to a broader one, in which humanitarianism covers situations ranging from poverty relief and assistance for ill immigrants and women suffering abuse, to assistance in natural disasters and conflicts (see Fassin 2012; Ticktin 2011).

Humanitarianism has a complex relationship to politics. It seeks to alleviate suffering, which often directly results or is exacerbated by political decision-making. The conduction of humanitarian action - or halt thereof (see Gottlieb, et al. 2012) - may partially be oriented to accomplishing policy change. In addition, humanitarianism becomes increasingly a key rationale in political decision-making, as Fassin convincingly argues in his analysis of 'humanitarian reason' and 'humanitarian government'. In his words, 'humanitarianism has become a language that inextricably links values and affects, and serves both to define and to justify discourses and practices of the government of human beings' (2012:2. See also Ticktin 2011).

The concept of medical neutrality has partially emerged as an attempt to organize the work of healthcare providers, especially during times of conflict (List 2008:238). In essence, it conceptualizes the relationship between the political and the medical. As is the case with humanitarianism, the definition of medical neutrality remains unstable. However, despite voices questioning the helpfulness of the concept (Rubenstein 2013), it continues to be used by the World Medical Association (WMA), Physicians for Human Rights, and others.

In contexts of violence, medical neutrality is often used to refer to the obligatory protection of health workers and infrastructure as well as their patients. According to the WMA (2012), health workers must have 'unimpeded passage' and 'access to patients, medical facilities and equipment', and should receive the assistance and protection needed to carry out their professional activities freely in 'complete professional independence'. Moreover, punishment and attempts to prevent medical staff 
Sophie Roborgh - Beyond Medical Humanitarianism

from acting in accordance with medical ethics are similarly not allowed (Footer and Rubenstein 2013:10).

Generally, this protection of the medical sector is at least partially reliant on the maintenance of certain standards. In their call for observing medical neutrality, the WMA emphasizes the need for health workers 'to abide by the rules of international medical ethics as well as the provisions of international humanitarian law as expressed in the Geneva Conventions' (2009). The humanitarian principle of 'impartiality' — consisting of non-discrimination, proportionality and absence of subjective distinctions (Mackintosh 2000:8) — is perhaps the most widely agreed upon standard. The ICRC defines impartiality as follows: '[The Movement] makes no discrimination as to nationality, race, religious beliefs, class or political opinions. It endeavours to relieve the suffering of individuals, being guided solely by their needs, and to give priority to the most urgent cases of distress' (2015:2). In addition, the Geneva Conventions stipulate that medical workers also have to refrain from 'acts harmful to the enemy' (Convention I, Article 21 1949. See also Heisler, et al. 2015).

The concept of medical neutrality has become further obscured with the politics surrounding humanitarian access. Humanitarian actors often gain access relying on adherence to a number of additional humanitarian principles, most notably neutrality and independence. The interpretation and operationalization of these principles is topic of intense discussion, especially in the case of 'neutrality' (see Schenkenberg van Mierop 2016a). Neutrality is defined by the ICRC as follows: 'In order to continue to enjoy the confidence of all, the Movement may not take sides in hostilities or engage at any time in controversies of a political, racial, religious or ideological nature' (2015:2). However, even active avoidance of explicit politicization is a political choice with 'political effects' (Redfield 2011:56; Terry 2000:3). 
Sophie Roborgh - Beyond Medical Humanitarianism

Crucially, it is unclear to what extent adherence to humanitarian principles discourages attacks, with organizations maintaining both rigid and flexible interpretations facing attack. However, the continuing reference to these principles by organizations - as well as assailants' justification of attacks by pointing at their alleged 'breach' - shows their continuing relevance in practice. Adherence therefore may not necessarily be legally obligatory, but is certainly strategically informed.

Several scholars call for a more context-specific interpretation of these principles, and the identity of those supposed to uphold them (Barnett and Weiss 2008:5; Redfield 2011:54). Different contexts provide notions of impartiality, neutrality, and independence with a different meaning and strategic significance, having differential impacts on the situation at hand. Examples of local medical humanitarianism in different settings shed light on this unstable, geographically and temporally contextualized constitution of medical neutrality among local medical actors.

This contextual awareness is reflected in my own, rather dynamic, understanding of the concept of medical neutrality. I understand medical neutrality in times of conflict as the active safeguarding of the immunity (in terms of protection from attack), impartiality, (and to a lesser extent neutrality) of the medical sector, in a continuous interaction between the medical sector and its political, security, and economic environment.

Local health workers occupy a difficult position in conflict. In the study of the MN in Egypt there are two contextual issues complicating the discussion. Firstly, the Egyptian case is legally an example of domestic, political unrest rather than an armed conflict and falls within the ICRC category of 'other emergencies'. This has important legal implications for the protection health workers can count on. Actions against protesters and health workers fall under law enforcement. In addition, human rights law applies instead of international humanitarian law. Although human rights law is theoretically well-equipped to offer protection, as Rubenstein and Footer (2013) argue, an ICRC report shows 
Sophie Roborgh - Beyond Medical Humanitarianism

many nations are yet to upgrade their legal system to the required standards (2015). It provides a different reading of medical humanitarian engagement as well. Contrary to international armed conflict, politicization of healthcare and overtly expressed support for one side over the other is no longer necessarily considered as patriotism, but as an indication of a much more contentious preference of one domestic political alternative over the other.

Secondly, the Egyptian local physicians under study are usually not technically members of officially recognized humanitarian organizations. Furthermore, depending on how broad a view is taken on the concept of humanitarianism (see above), not every physician who does his or her job, even voluntarily and with the aim to alleviate suffering, is necessarily a humanitarian in the strictest sense of the word. It is unclear which humanitarian principles they are expected to uphold, and what this adherence precisely entails in their situation. Rubenstein has argued persuasively that local health workers cannot and should not be expected to maintain neutrality (2013). However, I do think that their special access in times of political unrest and conflict — access often begrudgingly provided, and precluded to others - further complicates the situation, creating expectations that may not be legally required from them, but that they are nonetheless expected by combatants and other involved parties to maintain.

In the end, medical neutrality is a lived experience which is constantly being enacted by those who aim to uphold it (see Terry 2000:6). It is here where the Egyptian case serves as a lens, which helps understand how health workers read their engagement and activities within the uprising, providing important insight in the local constitution of medical neutrality.

\section{Methodology}


Sophie Roborgh - Beyond Medical Humanitarianism

This article draws on a social movement theory (SMT) approach to guide analysis of the organization, strategies, activities, and interactions of health workers active in the Egyptian uprising. SMT seeks to understand at what moments people decide to come together to push demands through (generally, contentious) action, and the response this elicits from other actors - often state authorities - at the receiving end of these demands (see McAdam, et al. 2004). A SMT prism illuminates different aspects of medical practice in situations of political turmoil, including ones where the medical sector faces attack, as was the case in Egypt.. It enables the exploration of the activities of physicians as a form of claims-making and activism that challenges the perception of a (largely unchanging) adherence to humanitarian considerations or to an identity as protester-physician. It reframes their activities as motivated by an ever-evolving process of meaning constitution, where yesterday's medical activities may have been differently motivated and interpreted than today's, even if they are highly similar (see Slim 2015:21).

For this purpose I explored the connection between health workers' (interpretation of) their identity as expressed in their statements, and their mobilization and participation patterns. I mapped the individual mobilization trajectories of 21 Egyptian health workers and two non-medical volunteers. I paid specific attention to moments of mobilization, extent of participation, and how activities were conducted. I combined this pattern of medical participation with interview statements of the same 24 health workers and volunteers (for one non-medical volunteer it was not possible to construct the mobilization trajectory based on interview data). In these interviews they expressed their motivations for engagement at key events and their understanding of their activities within the political context of that specific moment. The decision to combine their mobilization and participation pattern with their statements is based on the general unreliability of statements alone as a source of information on the meaning of an action. Activities can be colored significantly by personal experience, post-hoc justification of decisions, and the danger of recall bias (see Goffman 1974:9; Melucci 1996:386). I 
Sophie Roborgh - Beyond Medical Humanitarianism

then analysed the statements/pattern interaction among participants, discerning certain categories among the interviewees.

All interviews were semi-structured, and drew on an interview guide incorporating questions along seven lines of inquiry:

- engagement with medico-moral issues regarding neutrality and impartiality in the MN;

- network capacity building in the shape of organization strategies, alliance building, recruitment efforts, raising of donations, and other forms of resource mobilization;

- attacks and other obstructions to healthcare delivery experienced both collectively, and personally; - personal political background, ideas, and engagement both before and during the uprising;

- actual medical engagement before and during the uprising;

- general experiences as a physician or medical student in Egypt; and finally

- demographic details (including living situation, marital status, age, place in the family, religion, parental professional backgrounds, etc.).

I conducted all interviews in person and usually met interviewees several times. Interviews were undertaken in the period January 2014 - January 2015, with most occurring in August-September 2014. The location was of the interviewees' choosing, although I was sometimes asked for suggestions. Interviews occurred in a separate room in interviewees' offices, at their homes, in cafes, or even during drives. The vast majority of the interviews were recorded, with some containing both on and off-record parts. Access to the recordings is restricted to the author. All interviewees were informed before the interview of the purpose of this study, data use and management, and the fact that their participation is confidential and anonymous. Verbal consent was provided prior to the interviews. The study was approved by the Research Ethics committee of the Department of Politics and International Studies at the University of Cambridge. 
Sophie Roborgh - Beyond Medical Humanitarianism

Communication took place in the language that the interviewee preferred. Due to my moderate knowledge of Egyptian Arabic, and the superior English of interviewees, this was usually in English. Other conversations occurred in Egyptian Arabic (often in combination with English, or even German). On two occasions I brought a translator along. Off-record interviews with three additional health workers (not part of the sample) occurred with another researcher present. On three occasions, the health worker who introduced me to the new interviewee was present as well.

Reflecting the importance of Cairo in the medical community, the vast majority of health workers were active in Cairo, the main focus of the study. Two physicians were active in Alexandria and in al-Manșūra. The focus on Cairo reflects both the city's centrality in affecting political and social change, as well as pragmatic considerations of conducting research in its relative anonymity. Of the 24, 13 health workers and non-medical volunteers were independently active, while 11 belonged to network organizations. Three provided voluntary emergency care in public hospitals away from the protest sites, while most others were on the street. The sample contained 4 women and 20 men. The majority of interviewees was in the 25-35 age range. Nurses were under-represented in the MN networks, which is reflected in the group of interviewees. The sparsity of nurses also came to the fore in comments of interviewees, and in the broader make-up of official organizations.

I drew on six different points of access. I found the first interviewees through a local network of Egyptian and expatriate friends and colleagues. Further access points were found by contacting representatives of organizations, as well as through spontaneous encounters. After these initial contacts a snowball sampling approach was used. By using several access points, I aimed to minimize bias.

I also interviewed representatives of local and international organizations, such as the Egyptian Initiative for Personal Rights, the Association for Free Thought and Expression, al-Nadīm Center for 
Sophie Roborgh - Beyond Medical Humanitarianism

Rehabilitation of Victims of Violence and Torture, Tahrir Supplies, Law 'Andak Damm, World Health Organization - Egypt country office, Doctors Without Rights, and the International Committee of the Red Cross delegation - Cairo. Organizations were selected on the basis of their human rights or health care activities in Egypt. In total interviews with 40 people were conducted. Additional conversations (not part of this study) took place with a number of interviewees during the study and in its aftermath.

My position in relation to the networks was largely one of an outsider, as a non-national, a woman, and as a non-medic. It was clear to the interviewees I was in support of the Egyptian uprising against Mubarak, and sympathetic of the predicament they had experienced whilst doing their work. Over time, meaningful access gradually increased.

Interviews with participants were transcribed, and subsequently analyzed. Quotations underwent minimal cleaning for filler words and repetition. Participation trajectories were constructed by going chronologically through key events in the uprising, and asking interviewees if, where, and when they had worked (and whether they had protested as well). I also inquired more generally about the reason why they had become active in the MN, and asked about reasons for moments of absence.

The political situation in Egypt, the post-coup crackdown in particular, imposed a number of restrictions on contacting Muslim Brotherhood health workers. Although I talked to several sympathizers, including volunteers who had visited or participated in Brotherhood infrastructure, I was not able to interview official members of the Brotherhood. It was similarly difficult to reach nonparticipants of MN, who were nonetheless part of the same workplace, student circles, or friends of members of the network. 
Sophie Roborgh - Beyond Medical Humanitarianism

In Egypt, the word 'duktūr' (doctor) is not reserved for physicians alone. Crucially, in addition to physicians, some dentists and psychologists who were MN members also subscribed to and shaped the 'mìdānì' concept I will elaborate below. However, as the vast majority of the health workers in the sample were physicians (either graduated or in training), further research on larger sample sizes will have to show whether the insights gained here can be expanded to these health worker categories as well.

\section{Between political activism and medical neutrality}

In his analysis of the Gezi Park protests in Turkey, Aciksoz described how medical volunteers 'narrated their medico-political involvement in the protests in medico-ethical terms' in which there was an 'alignment of medical humanitarianism with social protest in the name of humanity' (2016:215). He assessed these medical volunteers to be medical humanitarians, who partook in emergency healthcare almost as 'a stimulus act that bypassed conscious reasoning and hence political contemplation'. He hence reviewed his interviewees' understanding of their medical participation 'not as a political gesture but as an inescapable ethical and professional obligation of health workers prescribed by the Hippocratic oath' (ibid.:208). Unlike Aciksoz' volunteers, the health workers and non-medical volunteers interviewed in the Egyptian case were strongly aware of the political implications of their medical and non-medical activities, imbued them with political meaning, and even specifically tailored them towards achieving political impact.

The evolution of the MN members' political conceptualization of medical engagement within the Egyptian uprising is detailed in the analysis of three distinct phases: January 2011-April 2012; May 2012-June 2013; and July 2013-August 2013.

Phase I: When political and humanitarian ideals overlap 
Sophie Roborgh - Beyond Medical Humanitarianism

When medical volunteers first arrived in Tahrīr Square, they did not just aim to treat the injured, but to change Egypt. MN's activities were not merely driven by humanitarian desires of providing care, but usually related to a political goal as well, namely the successful completion of the political revolution.

Being a 'revolutionary' was at this stage shared by practically all MN volunteers, and often made explicit. TDS forms a good example. Although most members emphasized in their interviews the unpolitical nature of TDS - specifically pointing out its adherence to the humanitarian principle of impartiality - many spoke of the revolutionary character of its members. Most of the physicians were protesters first and physicians second, even referring to themselves as 'medical activists' and 'revolutionaries'. One high-level TDS member commented how 'everyone in TDS is a revolutionary. That was the ticket for entering TDS. Actually, [..] they may not agree with one milyūnīa [million man march], or one idea. But basically, they were all pro-revolution'. Another member similarly mentioned that 'you would not find anybody against the principles of the revolution working as a field doctor'. Their organizations and work locations were similarly categorized as revolutionary. One of its key members referred to TDS as 'strongly related to the revolution'. He also described the position of the then TDS-managed 'Umar Makram mosque, Tahrīr Square's key field hospital, as 'the only place where there was still something from the revolution' during the Cabinet clashes.

One of the main manners in which MN volunteers conceptualized the political character of their engagement in this first phase was through their conviction that their medical activities were instrumental in sustaining the protests. They showed great awareness of the need to maintain the protesters' strength in numbers, especially in a revolutionary fight, and regarded MN services as central to accomplishing this. One TDS member, for instance, mentions 
Sophie Roborgh - Beyond Medical Humanitarianism

In the beginning, everybody [on the square] would count. If someone gets [injured], you lose someone in the fight. But if we [as health workers] enable you to get up and continue the fight, [the count] is getting even again... while on [the regime's] side, they don't have the same advantage.

The injured among the security forces would usually be taken out of the protests to receive treatment in medical centers and not be able to return as quickly.

According to the TDS member, maintaining the power in numbers of the protesters was of especial importance in a revolution, which he described as the "maximum polarization of two poles. One of them has to win. There is no negotiation, and there is no middle ground. So it is either this camp or the other, no matter what'. He concluded that ' $[t]$ here is this tension, because if you lost Tahrīr, you lost everything'.

Not only their medical activities themselves mattered, but also the very presence of physicians. A medical student explained how protesters (initially) trusted the physicians' judgment of the political situation. 'So when doctors are in the Square, we are on the right side. When doctors go home, our stay in the Square is a mistake. [In fact], when TDS left the Square, the number of people decreased'. Several interviewees recalled remarks by protesters signaling that the latter were more comfortable increasing their chance of injury, knowing that they could be helped close by. One physician commented 'People look up to you in a very striking way. They feel 'you can save my life if something happens to me'”.

Most MN members also participated in the different episodes of this phase of the uprising by protesting. Independent members, in particular, often preferred protesting over the hospital, feeling their presence on the frontline was more effective. For others, however, the revolutionary principles 
Sophie Roborgh - Beyond Medical Humanitarianism

were best upheld by participating only as practicing health workers. One health worker commented how he was a staunch revolutionary, but 'did not want to disrupt [human] life [by participating and potentially injuring others in the protest]. I just wanted to give other people the right to live. So, I said to myself, the most honorable route to take is being a medic in this situation'.

In this early phase (January 2011-April 2012), support for the uprising and MN's activities were ideologically intertwined. MN health workers considered dedication to ideals of humanitarianism, to ideals of revolution, and support for the Egyptian healthcare reform, and for specific revolutionary movements in the protests, as interconnected struggles. Consider the example of the health sector and Egypt's political fate. Regardless of ideological background and party preference, many interviewees subscribed to a vision in which lack of access to quality healthcare was an important driver of the persistent economic inequality and the presence of autocracy in the country. One physician and health policy expert explained, 'People are not sick because of viruses and bacteria, they are sick because they are poor and there is no health system'. The health revolution could help in the revolution against autocracy. Better healthcare, resulting in a mentally and physically healthy society, would form the basis for improved political and social participation, contributing to 'healthier', rights-based political rule. However, this healthcare revolution could in turn only be successful under democratic rule. Eradicating autocracy and accomplishment of right to health were hence two sides of the same coin. One health worker elaborated:

Inside TDS, we thought that everything is connected. The health issue of Egypt is connected to its political state. The regime should be eradicated from its roots, or replaced. [..] We entered the revolution as humans, and what brought us together in TDS is the humanitarian problem. [..] And we discovered that we have to fight the whole revolutionary fight in order to reach good medical health, and a basic level of human dignity. 
The uprising in general, and MN's activities contributing to it, were perceived as a means through which to bring about the social justice and dignity the health sector and society at large had been lacking.

What does the explicit inclusion of political goals in MN activities mean for the health workers' perception of humanitarian principles? One health worker mentioned how being a health worker and maintaining the ethics of the medical profession was a means of revolutionary support in itself. He stated how TDS is 'an organization formed by the revolution. The revolution brought us together, and we gathered on the basis of the revolutionary concept. But part of this concept is neutrality, impartiality, and the right of everyone to good treatment, to treatment respectful of human dignity'. In this first phase, the health workers felt strengthened in upholding (self-defined) notions of neutrality and impartiality when providing medical support, partially because of the political connotation of their medical work and their specific interpretation of revolutionary principles.

Their interest in social equality and human dignity was not only apparent in MN volunteers' appraisal of their medical (and non-medical) MN activities, but also in individual voting behavior and political activities. Most MN physicians were highly interested in politics. In a country with low election participation rates, $\mathrm{MN}$ doctors were the exception. Almost every interviewee relished the opportunity to vote after 2011 and the few who abstained, did so as a conscious decision out of political conviction, for instance in the controversial 2014 Presidential election that legitimated Sisi's reign. Some participated actively in political parties, including in positions of leadership, or were critical political commentators in the media on issues far exceeding medicine. Interestingly, it was this group of people with an interest in politics who ended up occupying central functions within TDS and the MN at large, often serving as brokers between $\mathrm{MN}$ and political groups, including ones with opposing viewpoints from their own parties. 
Despite their inclusive identity, suggesting a more heterogeneous group, many health workers connected to TDS, as well as independent health workers, subscribed to particular left-wing socialist and Nasserist ideas of social equality. This was visible in the expressed sympathy of a disproportionate number of individuals for the Revolutionary Socialists, Al-Thawra Mustamirra, and their support for the presidential bid of Neo-Nasserist Ḥamdīn Șabāhī.

Phase II: When MN-assisted protesters no longer reflect the health workers' own political convictions Without exception, all interviewees describe their MN contribution as driven by a deep desire to prevent the shedding of Egyptian blood. However, despite their expressed dedication to ideals of preserving human life and providing healthcare with complete impartiality, the continued participation of MN members in the protests was subjected to a constant process of evaluation.

The decision of MN volunteers to participate in the January 2011 revolution, Muhamad Mạ̣mūd (November 2011) and Cabinet clashes protests (December 2011) had been easy, since protesters who shared their political outlook needed treatment. It was in later protests, such as 'Abāsīya (May 2012) and al-Ittiḥādīya (December 2012), when Egyptian citizens were pitted against each other in increasingly polarized protests, that many volunteers dropped out of $\mathrm{MN}$ based on their political reading of the events. From the 'Abāsīya clashes (May 2012) onwards, when partisan politics came to dominate the protests, MN volunteers were no longer necessarily personally supportive of protesters' political goals. The notion that former revolutionary partners did not subscribe to the same revolutionary values as they did, was a rough awakening for some volunteers. This comes to the fore in the words of a medical student, who intervened to halt the beating up of a political opponent during the 'Abāsīya clashes. He mentioned, 
Sophie Roborgh - Beyond Medical Humanitarianism

['Abāsīya was] one of the moments that you realize that people who are on the same side, or acting like they are on the same side as you, don't share the same things that you believe in. [..] It was a very disturbing thing to know that there are people among us [the 'Ismā'îl supporters and supporting revolutionary partners in 'Abāsīya] who have no problem with torturing.

Health workers faced a dilemma: if their contribution mattered so much for the outcome of protests, should they engage with the protests of political opponents who-in their perspective - opposed their revolutionary goals of human dignity and social equality? If Aciksoz' aforementioned assertion, that medical volunteers engage in a humanitarianism-driven mental shortcut, bypassing political decisionmaking, holds true in the Egyptian case, there should be little difference visible in volunteer engagement beyond the regular fluctuation in participation rates caused by decrease of biographical availability or participation fatigue.

However, the political interpretation of their medical activities affected many MN volunteers' willingness to provide assistance in these more polarized clashes to people they often considered their political opponents. As the protests continued, several volunteers demobilized on ideological grounds. Crucially, the volunteers who continued their medical activities in these protests, now often legitimized their presence by disentangling their medical and humanitarian persona from their party political one. MN's presence was no longer framed as a form of political support for the protesters' political organizations and agendas. Volunteers now claimed they were present in a position of service delivery out of humanitarian considerations alone, and to support the right of people to protest, which they considered part and parcel of the revolutionary agenda. The same medical student expressed:

I don't think it is right to let these people [protesters of an opposing political group] face their death alone. I don't support these people, I don't support their demands, and I don't 
Sophie Roborgh - Beyond Medical Humanitarianism

think they protest for anyone except themselves. But I can’t accept firing at them. I can't deal with the idea that they are facing death and no one is doing anything, even if I think they are a bunch of idiots.

A physician remarked:

TDS participated in events that we did not agree with ...they weren't the revolutionary events [events of political movements they perceived as being pro-revolution]. In those, we meant to be there with our badges, with our flags, with our vests, with everything. We meant to say, that we may not agree with a particular demonstration, but we want to support everyone's rights to demonstrate in this country.

Phase III: When MN assistance directly benefits political adversaries and creates a potential backlash

The MN came under even more pressure a year later, during the pro-Morsy protests and sit-ins in the summer of 2013. Never before had protests been this politicized, as Egyptians rallied to depose their first elected President. Many MN volunteers were strongly supportive and even involved in the organization of these protests, feeling that Muslim Brotherhood rule had turned decisively authoritarian, and in some cases personally blaming Morsy for the death of one of their most beloved volunteers, Kristy, at the hands of security forces (see Ahram Online 2013).

In contrast to their conviction to participate in the protests against Morsy, they were unsure how to navigate the post-ouster sit-ins of Muslim Brotherhood supporters. MN physicians who had mobilized in almost all previous events wanted to continue to do 'the right thing', but became increasingly uncertain what this entailed as public opinion had become highly critical of the Brotherhood. 
Since volunteers perceived that their medical assistance could strengthen the protests-or at least sustain them — some had trouble deciding if providing medical assistance to the Muslim Brotherhood was ethically and politically desirable. In this dilemma, a number of factors were taken into account, including the political situation, the public opinion, and the increased risk of participation in the protests. For the first time, the concern for one's personal safety became an important issue for the volunteers. One health worker reflected on his participation in the Al-Nahḍa sit-in, saying that he realized that there was a considerable risk of taking a bullet there. The expectation of severe violence was so high (see HRW 2014) that a KRC medical student commented how the large Rābi'a al'Adawiyya sit-in 'was like a gathering to die'. It seemed an awfully high price to pay for assistance to people you do not agree with.

But more personal factors were also at play, such as the extent of their dedication to the right to health and right to protest, pressure from family and friends, and for some, even religious considerations concerning the consequences for their afterlife as believers. One TDS physician drew historical parallels between the period of fitna [communal disorder] which took place after the death of the Prophet Mohamed, and the political situation in post-coup Egypt:

I don't know anymore whether the Muslim Brotherhood is right or wrong, whether what I am doing is right or wrong. [..] If I am going to be killed tomorrow in a protest march, will I go to heaven? Before, the picture was very clear. Mubarak was wrong and the revolution was right. After splitting the revolution, and re-splitting the revolution, and really, really splitting the revolution, this line started to vanish. In Islamic theories, we call it fitna: a time when you don't know the difference between right and wrong. And our Prophet said that when you reach this time, you should wait. So until things become clearer, we have planned to stay at home. 
Even those who had still participated with conviction in 'Abāsīya (May 2012) and al-Ittiḥādīya (December 2012) now started to waver. The decision regarding whether to continue medical support during the Muslim Brotherhood sit-ins split the group of remaining MN volunteers. Groups such as TDS increasingly experienced animosity from Brotherhood protesters, some of whom considered TDS at large, and some outspoken members in particular, complicit in creating the Brotherhood's predicament. TDS therefore largely scaled back their engagement from a physical presence in the protest event to providing logistical support. Instead, some MN members helped out in a personal capacity.

Interviewees who provided medical assistance to the Muslim Brotherhood sit-ins were quick to inform me that they had no sympathy for the Brotherhood's politics, and that their participation was purely based on humanitarian grounds. Interestingly, the volunteers who were the most willing to assist the Muslim Brotherhood, were the most wedded to the revolutionary principles. One physician recalls how the volunteers who opposed the Brotherhood most vehemently in street protests on political grounds, were the first ones to stand up for the Brothers' rights and to extend their help to them. Some volunteers, who noticed they felt resentment towards the Brotherhood supporters, ended up over-compensating for this sentiment, in order to prove their humanitarian credentials to themselves. One physician, for example, was not in Cairo at the time of the crackdown on the MB sit-ins. However, he was adamant that if he had been there, he would have volunteered, as he had done at other occasions, stating he wanted to prove his principles to himself. For such volunteers, their dedication to humanitarian ideals overruled any political disagreement they might personally have with the Brotherhood.

The crackdown following the 'popular coup' has taken a huge toll on the MN. From that moment on, not only the Muslim Brotherhood, but the 25 January revolution at large, have come under fire from the public and authorities. The military managed to mobilize the masses against the revolution, and a 
Sophie Roborgh - Beyond Medical Humanitarianism

narrative of the 25 January revolution as a conspiracy to destroy the country has become widespread. This has demoralized many volunteers. One health worker stated how this loss of public faith in the revolution severely affected him:

It is not just the idea of being without hope for the future of the revolution, it is also the idea of 'Was it worth it?' Everybody began to ask themselves, 'Is it worth to spend my life, to risk my life, for such an [idiotic] dream?

\section{The mīdānī physician}

In accordance with the general notion that 'people commit themselves to movements in stages, each activity preparing the way for the next' (McAdam 1988, 51), different moments of decision-making and various degrees of involvement could be observed in which volunteers intensified their participation, scaled back, or even ended their engagement within a particular protest, or even with $\mathrm{MN}$ at large. In these decisions, the volunteers took their experiences in previous protests into account, as well as their activities in other organizations (see also Taylor, et al. 2009: 869,886).

Over time an ever-smaller core group of volunteers remained active in the $\mathrm{MN}$, who subscribed to a particular notion of physicianhood, the 'mìdān' physician. I coin this term to analyze a rising generation of health workers engaged in voluntary medical mobilization. 'Mīdān' in written Arabic (and Egyptian colloquial pronunciation) means 'field', but also 'square'. Its meaning reflects both MN activities in the field, such as the establishment of field hospitals, as well as their link to Tahriir Square, which became the primary location for its activities. (Some physicians in the Square called themselves mìdāni physicians, but this has no connection to the specific analytical category for which I employ this term.)

The mìdānī physician describes a type of local physician, who 
Sophie Roborgh - Beyond Medical Humanitarianism

a) is highly politicized on a personal basis and contributes to medical organizations that are often openly political. By the adjective 'political', I mean that these individuals and organizations engage by either act or expression on topics surpassing medicine and public health. Alternatively, as is often the case, they may rely on a tenuous connection between a statement on a political event and the event's implications for public health. I understand the assessment of this 'political' character is subjective, and caution for its conservative use. As an example in this study, TDS offered a strongly-worded statement decrying Egypt's silence on Israeli flight sorties over Syria (2013). I interpreted this as a political statement, as the connection to public health was weak.

a) seeks to reconcile this political position with adherence to humanitarian principles of humanity, impartiality, and to a lesser degree, neutrality in provision of care.

The collective identity of mīdāni physicians mostly emerged through participating in groups with specific organizational structures and collaboration patterns, which balanced politicization of both medical and non-medical activities on the one hand with adherence to principles of impartiality, and to a more limited degree, neutrality and independence, on the other (Unpublished results). In addition to physicians, also other types of health workers shaped and subscribed to the characteristics of the 'mīdān' health worker, as shown in the response by dentists and psychologists in the sample. However, due to their limited numbers in this study, I have been hesitant to expand the concept to these categories without additional research.

\section{Conclusion}

This article describes the complexity of the integration of revolutionary politics and medical humanitarian assistance by medical volunteers in the Egyptian uprising. It further nuanced our understanding of volunteers' efforts in resolving the tensions between their political and medical ethical and humanitarian convictions, showing how there was deep awareness of this tension. It illuminated the manner in which local medical-humanitarian engagement was conceptualized in a 
Sophie Roborgh - Beyond Medical Humanitarianism

collective and iterative fashion. It exemplifies the consciously constituted, deeply contextualized, and, hence, unstable interpretation of medical neutrality among local health workers.

Drawing on an approach which combined statements with mobilization and participation patterns, I traced the evolution of Egyptian health workers' interpretation of their participation in the uprising, distinguishing three separate phases. In the first phase, revolutionary, party political, and humanitarian goals still largely overlapped. From the second phase onwards, with the increasing polarization within Egyptian society, these goals started to diverge. Increasingly, medical engagement became less an expression of support for the protesters' demands, but an expression of dedication to humanitarian ideals, and the revolutionary principles. In the third phase, humanitarian and political convictions became irreconcilable for many. Only few remained. The figure of the politicized mīdann physician, who came to dominate the diminishing body of MN volunteers over time, consciously attempted to reconcile his/her political and medical-humanitarian convictions. Preliminary exploration of other instances of medical involvement in anti-authoritarian protests suggests that the mìdānì type may not be a strictly Egyptian phenomenon, but may be a category of health workers which has mobilized in protests in other geographical settings as well, for instance in Turkey and (initially) in Ukraine's Euromaidan protests.

\section{REFERENCES}

1949. Geneva Convention (I) for the Amelioration of the Condition of the Wounded and Sick in Armed Forces in the Field of 12 August 1949, Art. 21. Retrieved 21 April, 2018 (https://www.icrc.org/eng/assets/files/ publications/icrc-002-0173.pdf).

Abdelrahman, Maha. 2015. Egypt's Long Revolution: Protest Movements and Uprisings. London and New York: Routledge. 
Sophie Roborgh - Beyond Medical Humanitarianism

Abramowitz, Sharon, and Catherine Panter-Brick (eds.). 2015. Medical Humanitarianism

Ethnographies of Practice. Philadelphia: University of Pennsylvania Press.Aciksoz, Salih. C. 2016.

"Medical Humanitarianism Under Atmospheric Violence: Health Professionals in the 2013 Gezi

Protests in Turkey." Cult Med Psychiatry 40 (198):198-222. doi:10.1007/s11013-015-9467-2.

Abouzeid, Rania. 2011. “The Clash of the Two Egypts: Tahrir Square Vs. Abbasiya Square.” Time, December 24. Retrieved 23 June, 2018

(http://content.time.com/time/world/article/0,8599,2103050,00.html).

Adams, Vincanne. 1998. Doctors for Democracy - Health Professionals in the Nepal Revolution.

Cambridge: Cambridge University Press.

AFP. 2013. “Timeline: The One-Year Rule of Egypt's Morsy.” Egypt Independent, July 4.

Retrieved 23 June, 2018 (http://www.egyptindependent.com/news/timeline-one-year-rule-egypt-smorsy).

Ahram Online. 2011a. “Live Updates: Egypt's 'Friday of One Demand' as It Unfolds,” November 18. Retrieved 23 June, 2018 (http://english.ahram.org.eg/NewsContent/1/64/26857/Egypt/Politics/Live-Updates-Egypts-Friday-of--One-Demand-as-it-un.aspx).

Ahram Online. 2011b. "Egypt Revolution Relaunched: Live Updates of 'Martyrs' Friday'.” November 25. Retrieved 23 June, 2018

(http://english.ahram.org.eg/NewsContent/1/64/27558/Egypt/Politics-/Egypt-RevolutionRelaunched-Liveupdates-of-Martyr.aspx).

Ahram Online. 2012a. "Updated: At Least 11 Dead in Attack on Egypt's Abbasiya Sit-In.” May 2. Retrieved 23 June, 2018 (http://english.ahram.org.eg/NewsContent/1/64/40629/Egypt/Politics/Updated-At-least--dead-in-attack-on-Egypts-Abbasiy.aspx). 
Sophie Roborgh - Beyond Medical Humanitarianism

Ahram Online. 2012b. "Hundreds March to Commemorate Mohamed Mahmoud 'heroes'."

November 13. Retrieved 23 June, 2018

(http://english.ahram.org.eg/NewsContent/1/64/58023/Egypt/Politics-/Hundreds-march-tocommemorate-Mohamed-Mahmoud-hero.aspx).

Ahram Online. 2013. "Tahrir Doctors head says killing of activist Kristy was premeditated." February 7. Retrieved 20 April, 2018

(http://english.ahram.org.eg/NewsContent/1/64/64233/Egypt/Politics-/Tahrir-Doctors-head-sayskilling-of-activist-Krist.aspx).

Ahram Online, and Ahmed Feteha. 2011. "Egypt Military Attacks Occupy Cabinet Protesters: Updates from the Day.” Ahram Online, December 16. Retrieved 23 June, 2018 (http://english.ahram.org.eg/NewsContent/1/64/29489/Egypt/Politics-/Egypt-military-attacksOccupy-Cabinet-protesters-U.aspx).

Ahram Online, and Nada Hussein Rashwan. 2012. “"This Is Not Politics, but Interests,' Says MB Supreme Guide of Current Protests." Ahram Online, December 8. Retrieved 23 June, 2018 (http://english.ahram.org.eg/NewsContent/1/64/60059/Egypt/Politics-/This-isnot-politics,-butinterests,-says-MB-Supre.aspx).

Al-Arabiya with agencies. 2012. "Egypt Imposes Curfew in Abbassiya after Clashes; 2 Killed, 296 Injured, 170 Arrested.” Al-Arabiya, May 4. Currently no longer available (https://english.alarabiya.net/articles/2012/05/04/212064.html).

Al-Bedaiah. 2013. “Al-’amn yuṭliq al-ghāz 'alā al-mustashfā al-maydānī bi-kanīsa qaṣr al-dūbāra.. wa rā '̄i al- kanīsa: mustamirūn fi 'ilāj al-mușābiyīn.” January 25. Retrieved 1 September, 2016 (http://albedaiah.com/node/17164).

Alexander, Anne, and Mostafa Bassiouny. 2014. Bread, Freedom, Social Justice: Workers and the Egyptian Revolution. London: Zed Books. 
Sophie Roborgh - Beyond Medical Humanitarianism

Ali, Randa. 2012. "Witnesses to Friday Tahrir Clashes Pin Blame on Muslim Brotherhood." Ahram Online, October 14. Retrieved 23 June, 2018 (http://english.ahram.org.eg/News/55597.aspx).

Al-Khalfwai, Sayed. 2013. "Muslim Brotherhood to Participate in Memorial of Cabinet Clashes." The Cairo Post, December 16. Retrieved 23 June, 2018

(http://thecairopost.youm7.com/news/56328/news/muslim-brotherhood-participate-memorialcabinet-clashes).

Barnett, Michael, and Thomas G. Weiss. 2008. "Humanitarianism: A Brief History of the Present." Pp.1-48 in Humanitarianism in Question: Politics, Power, Ethics, edited by Barnett, Michael and Thomas G. Weiss. Ithaca: Cornell University Press.

BBC. 2013. "Profile: Egypt's Tamarod Protest Movement," July 1. Retrieved 23 June, 2018 (https://www.bbc.co.uk/news/world-middle-east-23131953).

Cairo Institute for Human Rights Studies (CIHRS). 2012. “Al-Ittihadiyya - 'Presidential Palace' Clashes in Cairo 5- 6 December 2012." Cairo. Retrieved 23 June, 2018 (http://www.cihrs.org/wpcontent/uploads/2012/12/Ittihadiyya.rep_.CIHRS_.Eng_.Dec_.pdf).

CNN Wire Staff. 2011. “One Killed, More than 300 Injured as Clashes Break out in Egypt.” CNN, May 5. Retrieved 23 June, 2018 (https://edition.cnn.com/2012/05/04/world/africa/egyptprotests/index.html).

CNN Wire Staff. 2012. "Egypt Imposes Curfew Following Deadly Clashes.” CNN, May 5. Retrieved 23 June, 2018 (http://edition.cnn.com/2012/05/05/world/meast/egypt-unrest/).

Dewachi, Omar. 2017. Ungovernable Life: Mandatory Medicine and Statecraft in Iraq. Stanford, CA.: Stanford University Press. 
Sophie Roborgh - Beyond Medical Humanitarianism

Egypt Independent. 2012. "Update: SCAF Enforces Curfew in Abbasseya, Clashes Continue.” Egypt Independent, May 4. Retrieved 23 June, 2018 (http://www.egyptindependent.com/updatedozens-alexandria-arrive-abbasseya-sit/).

El Gundy, Zeinab. 2011. "Friday 'Honour' Demo Draws Thousands to Egypt's Tahrir Square.” Ahram Online, December 23. Retrieved 23 June, 2018 (http://english.ahram.org.eg/NewsContent/1/64/30035/Egypt/Politics-/Friday-Honourdemo-drawsthousands-to-Egypts-Tahri.aspx).

El-Sharnoubi, Osman., Bel Trew, Randa Ali, and Sherif Tarek. 2012. "Rival Constitution Demonstrations Start across Egypt.” Ahram Online, December 11. Retrieved 23 June, 2018 (http://english.ahram.org.eg/NewsContent/1/0/60294/Egypt/0/Rival-constitution-demonstrationsstart-across-Egy.aspx).

Eskandar, Wael. 2012. "Year of the SCAF: A Time-Line of Mounting Repression." Ahram Online, February 11. Retrieved 23 June, 2018 (http://english.ahram.org.eg/NewsContent/1/64/34046/Egypt/Politics-/Year-of-the-SCAF-atimelineof-mounting-repression.aspx).

Fassin, Didier. 2012. Humanitarian Reason: A Moral History of the Present Times. Berkeley and Los Angeles, CA: University of California Press.

Feteha, Ahmed, and Sherif Tarek. 2011. “Live Updates: Egypt's Police Forcibly Disperses Protesters from Tahrir, Incites More Activists to Join and Resist.” Ahram Online. November 19. Retrieved 23 June, 2018 (http://english.ahram.org.eg/NewsContent/1/64/26969/Egypt/Politics/Live-Updates-Egypts-police-forcibly-disperses-prot.aspx).

Footer, Katherine. H. A., and Leonard. S. Rubenstein. 2013. "A Human Rights Approach to Health Care in Conflict.” International Review of the Red Cross 95 (889):167-87. doi:10.1017/S1816383113000349. 
Sophie Roborgh - Beyond Medical Humanitarianism

Footer, Katherine. H. A., Sarah Meyer, Susan G. Sherman, and Leonard S. Rubenstein. 2014. “On the Frontline of Eastern Burma's Chronic Conflict - Listening to the Voices of Local Health Workers.” Social Science \& Medicine 120: 378-86.

Fouad, Fouad M., Annie Sparrow, et al. 2017. "Health workers and the weaponisation of health care in Syria: a preliminary inquiry for The Lancet - American University of Beirut Commission on Syria.” The Lancet, Published online 14 March 2017.

Goffman, Erving. 1974. Frame Analysis: An Essay on the Organization of Experience. Cambridge, Mass.: Harvard University Press.

Gottlieb, Nora, Dani Filic, and Nadav Davidovitch. 2012. "Medical humanitarianism, human rights and political advocacy: The case of the Israeli Open Clinic.” Social Science and Medicine 74: 839845.

Hamdy, Sherine F., and Soha Bayoumi. 2016. "Egypt's Popular Uprising and the Stakes of Medical Neutrality." Cult Med Psychiatry Jun;40 (2):223-241.

Heisler, Michele, Elise Baker, and Donna McKay. 2015. Attacks on Health Care in Syria Normalizing Violations on Medical Neutrality? N Engl J Med 373:2489-2491.

Human Rights Watch. 2012a. "Egypt: Widespread Military Torture of Protesters Arrested in May Impunity Enables Further Abuse,” May 19. Retrieved 23 June, 2018 (https://www.hrw.org/news/2012/05/19/egypt-widespread-military-torture-protesters-arrested-may).

—. 2012b. "Egypt: Protester Killings a Test for Morsy - Impunity Reigns: No Justice, Police Reform One Year Later.” Human Rights Watch. November 19. Retrieved 23 June, 2018 (https://www.hrw.org/news/2012/11/19/egypt-protester-killings-test-morsy). 
Sophie Roborgh - Beyond Medical Humanitarianism

—. 2012c. "Egypt: Morsy Decree Undermines Rule of Law - New Law May Bring Some Accountability but Invites Abuse of Freedoms,” November 26. Retrieved 23 June, 2018 (https://www.hrw.org/news/2012/11/26/egypt-morsy-decree-undermines-rule-law).

-. 2014. All According to Plan - The Rab'a Massacre and Mass Killings of Protesters in Egypt. Retrieved September 1, 2016 (https:// www.hrw.org/report/2014/08/12/all-according-plan/rabamassacre-and-mass-killings-protesters-egypt).

ICRC. 2015. Domestic Normative Frameworks for the Protection of Health Care. Retrieved April 21, 2018 (https://shop.icrc.org/cadres-normatifs-nationaux-pour-la-protection-des-soins-desante.html?__store=default).

Iliffe, John. 1998. East African Doctors - A History of the Modern Profession. African Series. Cambridge: Cambridge University Press.

List, Justin M. 2008. “Medical Neutrality and Political Activism: Physicians' Roles in Conflict Situations." Pp. 237-255 in Physicians at War: The Dual-Loyalties Challenge, edited by Allhoff, Fritz. Dordrecht: Springer Netherlands.

Mackintosh, Kate. 2000. The Principles of Humanitarian Action in International Humanitarian Law. Humanitarian Policy Group - Overseas Development Institute. Retrieved 21 April, 2018 (https://www.odi.org/sites/odi.org.uk/files/odi-assets/publications-opinion-files/305.pdf).

McAdam, Doug. 1988 (1990 paperback edition). Freedom Summer. New York: Oxford University Press.

McAdam, Doug, Sidney Tarrow, and Charles Tilly. 2004. Dynamics of Contention. Second edition. Cambridge: Cambridge University Press.

Melucci, Alberto. 1996. Challenging Codes. Cambridge: Cambridge University Press. 
Sophie Roborgh - Beyond Medical Humanitarianism

Overseas Security Advisory Council. 2012. "Emergency Message to U.S. Citizens: Cairo (Egypt), Clashes in Abbassia.” May 2. Retrieved 23 June, 2018

(https://www.osac.gov/pages/ContentReportDetails.aspx?cid=12428).

Peterson, Jenny H. 2015. "Introduction.” Pp. 1-9 in The Routledge Companion to Humanitarian Action, edited by Mac Ginty, Roger, and Jenny H. Peterson. London and New York: Routledge.

Redfield, Peter 2011. “The Impossible Problem of Neutrality.” Pp. 53-70 in Forces of Compassion:

Humanitarianism Between Ethics and Politics, edited by Erica Bornstein and Peter Redfield. Santa Fe: School for Advanced Research Press.

Rosefsky Wickham, Carrie. 1997. "Islamic Mobilization and Political Change: The Islamic Trend in Egypt's Professional Associations”. Pp. 120-135 in Political Islam: Essays from Middle East Report, edited by Beinin, Joel, and Joe Stork. Berkeley: University of California Press.

RT. 2012. "Two Dead, 300 Injured, 170 Arrested: Egypt Imposes Curfew after Abbasiya Violence," May 4. Retrieved 23 June, 2018 (https://www.rt.com/news/clashes-egypt-erupt-troops-590/).

Rubenstein, Leonard S. 2013. “A Way Forward in Protecting Health Services in Conflict: Moving beyond the Humanitarian Paradigm.” International Review of the Red Cross 95 (890):331-40.

Schenkenberg van Mierop, Ed. 2016a. "Coming clean on neutrality and independence: The need to assess humanitarian principles.” International Review of the Red Cross 97 (897/898):295-318.

— 2016b. "The challenges of localised humanitarian aid in armed conflict." MSF Emergency Gap Series, November 2016.

Shub‘ān, ‘A. 2012. 'Fi dhikrī muhamad maḥmūd - Kinīsa <<Qaṣr al-dūbāra〉>.. nuqța ḍaw’ fī 'ayām al-khartūsh wa al-dakhān.’” Al-Wafd website, November 18. 
Sophie Roborgh - Beyond Medical Humanitarianism

Shams El-Din, Mai. 2011. "Protesters Blame SCAF for Abbasiya Clashes." Daily News Egypt, July

25. Retrieved 23 June, 2018 (http://www.dailynewsegypt.com/2011/07/25/protesters-blame-scaffor-abbasiya-clashes/).

Shukrallah, Salma, Mohamed Nada, Nada El-Kouny, Hazel Haddon, Sherif Tarek, Hatem Maher, Ahmed Feteha, and Osman El-Sharnoubi. 2012. “A Bloody Night at Egypt's Presidential Palace.” December 6. Retrieved 23 June, 2018 (http://english.ahram.org.eg/NewsAFCON/2017/59852.aspx).

Slim, Hugo. 2015. "Wonderful Work - Globalizing the Ethics of Humanitarian Action.” Pp. 13-25 in The Routledge Companion to Humanitarian Action, edited by Mac Ginty, Roger, and Jenny H. Peterson. London and New York: Routledge.

Sousa, Cindy, and Amy Hagopian. 2011. “Conflict, Health Care and Professional Perseverance: A Qualitative Study in the West Bank." Global Public Health 6 (5):520-33.

TDS. 2013. "Bayān 'ājil: al-țarad al-fawrī li-l-safīr al-ṣahyūn̄̄ wa mu āqaba al-ihtilāl huwa 'aqal rad maqbūl." May 7. https://www.facebook.com/tahrirdoctors/photos/a. 284635694884656.88309.231414563540103/637786059569616/?type=3\& theater.

Taylor, Verta, Katrina Kimport, Nella Van Dyke, and Ellen A. Andersen. 2009. "Culture and Mobilization: Tactical Repertoires, Same-Sex Weddings, and the Impact on Gay Activism.” American Sociological Review 74:865-890.

Terry, Fiona. 2000. “The Principle of Neutrality: Is It Relevant to MSF? - Discussion Paper for 2001 Mini-AGS."

(https://www.researchgate.net/publication/237122178_The_principle_of_neutrality_is_it_relevant_t o_MSF)

Ticktin, Miriam I. 2011. Casualties of care: immigration and the politics of humanitarianism. Berkeley and Los Angeles, CA: University of California Press. 
Sophie Roborgh - Beyond Medical Humanitarianism

World Medical Association (WMA). 2009. "WMA urges medical neutrality in times of conflict."

15 May. Retrieved April 21, 2018 (https://www.wma.net/news-post/wma-urges-medical-neutralityin-times-of-conflict/).

— . 2012. "WMA Regulations in Times of Armed Conflict and Other Situations of Violence."

Retrieved September 1, 2016 (http://www.wma.net/en/30publications/10policies/a20/). 